\section{Sosyal Pazarlama Faaliyetlerinin Satın Alma Davranışına Etkisi}

\section{Suleyman Can Yildirir ${ }^{\mathrm{a}}$}

Öz: Yirminci yüzyılın ortalarına doğru sosyal sorunlar neredeyse tüm dünya ülkeleri tarafından yakın takibe alınmaya başlanmıştır. Gerek ülkelerin ve kurumların konu ile ilgili düzenlemeleri gerekse insanların konuya bakış açıları neticesinde işletmeler de faaliyetlerinde sosyal konulara göre sistem oluşturma yoluna gitmişlerdir. Bu da sosyal sorumluluk anlayışı içerisinde, toplumsal fayda yaratan sosyal pazarlama faaliyetlerine yönlenmeyi beraberinde getirmiştir. Bu çalışmanın amacı, işletmelerin sosyal pazarlama faaliyetlerinin, tüketicilerin tutum, satın alma niyeti ve davranışları üzerindeki etkisini incelemektir. Ayrıca tüketicilerin demografik özelliklerine göre sosyal pazarlama faaliyetlerine karşı tutumları arasında bir farklılık olup olmadığının belirlenmesi de hedeflenmektedir. Örneklemi belirleme aşamasında kolayda örneklem metodundan faydalanılmıştır. Ulaşılan verilerin 383 adedi yapısal eşitlik modellemesi uygulanması için uygun bulunmuştur. Gerçekleştirilen çalışmada, tüketicilerin genellikle spor, sağlık, kültür, çevre ve enerji gibi konularda sosyal fayda yaratan ve bunu da kitle iletişim araçları ile topluma yayan işletmeleri daha çok tercih ettikleri bulgusuna ulaşılmıştır. Ayrıca katılımcıların, sosyal fayda yaratan işletmelerin ürünlerine aynı kalitede daha ucuz olan başka bir ürüne kıyasla daha fazla para harcayabilecekleri bulgusuna da ulaşılmıştır.

\section{The Effects of Social Marketing Activities on Purchasing Behaviour}

\begin{abstract}
Social problems have been monitored closely by almost all countries since the middle of the 20th century. Regarding the subject, the regulations of the countries and institutions, as well as the perspective of the people, have pushed the enterprises to create systems for social issues in their activities. The aim of this study is to examine the effects of enterprises' social marketing activities on attitudes, buying intentions, and behaviors of consumers. In addition, it is aimed to determine whether there is a difference between the attitudes of consumers towards social marketing activities according to their demographic characteristics. The convenience sampling method was used for the selection of samples. 383 data were obtained and structural equation modeling was used for analysis. Results of the study show that consumers prefer the companies which make social benefits, also they prefer the firms which disseminate these activities via the mass medium. Likewise, consumers who have participated in the study said that they might pay more to the products and firms that make social benefits than the other same quality and cheaper products.
\end{abstract}

Anahtar Sözcükler: Sosyal Pazarlama, Tutum, Niyet, Davranış, Tüketici

JEL: M30, M31

$\begin{array}{ll}\text { Geliş } & : 21 \text { Aralık } 2020 \\ \text { Düzeltme } & : 25 \text { Mart } 2021 \\ \text { Kabul } & : 12 \text { Mayıs } 2021 \\ \text { Tür } & : \text { Araştırma }\end{array}$

Keywords: Social marketing, Attitude, Intention, Behavior, Consumer

JEL: M30, M31

$\begin{array}{ll}\text { Received } & : 21 \text { December } 2020 \\ \text { Revised } & : 25 \text { March } 2021 \\ \text { Accepted } & : 12 \text { May } 2021 \\ \text { Type } & : \text { Research }\end{array}$




\section{Giriş}

Son yıllarda, ekonomik ve sosyal sorunlar ile çevre sorunları birçok işletmeyi tüketicilerle ortak bir çalışma içerisine girmeye yönlendirdi. İ̧letmeler, hem küresel çevrecilik yarışında yüksek sıralarda yer almak hem de çevreci tüketici gruplarına seslenebilmek adına çalışma prensiplerinde çeşitli düzenlemeler yaptı. Işletmeler sosyal pazarlama aracılığıyla tüketicilere ulaşmak ve modern zamana adapte olmak adına bazı girişimlerde bulunmuşlardır.

Çalışmanın temel problemini, çevreye duyarlı ve sosyal pazarlama anlayışı içerisinde faaliyetlerini sürdüren işletmelerin, bu sosyal pazarlama faaliyetlerini tüketicilere ne ölçüde yansıtabildikleri ve tüketicilerin söz konusu faaliyetler hakkındaki değerlendirmeleri oluşturmaktadır. Bu problemin çözümü için yapılan araştırmada tüketicilerin, işletmelerin sosyal pazarlama faaliyetlerini değerlendirme kriterlerinin de tespit edilmesi hedeflenmiştir.

Literatür incelendiğinde sosyal pazarlama yaklaşımı ile ilgili birçok çalışma ve kitap olduğu görülmektedir. Çalışmada işletmelerin sosyal pazarlama faaliyetlerinin, tüketicilerin tutum, satın alma niyeti ve davranışları üzerindeki etkisini incelemenin yanı sıra tüketicilerin demografik özelliklerine göre sosyal pazarlama faaliyetlerine karşı tutumları arasında bir farklılık olup olmadığının belirlenmesi de amaçlanmaktadır.

Bu çalışma, tüketicilerin sosyal pazarlama faaliyetlerine karşı tutum, niyet ve davranışlarını incelemesi sonucunda ileride öğrenciler ya da akademisyenler tarafından yapılacak çalışmalar için faydalı bir kaynak olabilecektir. Ayrıca tüketicilerin sosyal pazarlama faaliyetleri hakkındaki değerlendirmelerine ulaşılabilmesi açısından işletmeler için de kullanılabilir bir mehaz özelliği olduğu değerlendirilmeketdir. Bu çalışmanın, konu ile ilgili yeterli bilimsel çalışma olmaması sebebiyle, tüketicilerin tutum ve niyetlerini inceleyerek bir sosyal pazarlama strateji geliştirmeyi planlayan işletmeler ve gelecekte yapılacak olan çalışmalara ışık tutması hedeflenmektedir.

\section{Kavramsal Çerçeve}

\subsection{Sosyal Pazarlamanın Tanımı ve Özellikleri}

Kotler ve Zaltman (1971)'a göre sosyal pazarlama tek başına bir teori olmaktan ziyade, psikoloji, antropoloji ve iletişim gibi birçok farklı yaklaşımın bir araya gelerek insanların davranışlarını etkileyemeye yönelik oluşturduğu bir teoridir. Ewing (2001) ise sosyal pazarlamayı, sosyal değişiklik yaratacak bazı programların tasarlanarak pazarlama faaliyetlerine dâhil edilmesi ve uygulanması olarak tanımlamıştır. Sosyal pazarlama, "hedef kitlenin veya toplumun bir bütün olarak sağlığını ve iyiliğini geliştirme doğrultusunda olumlu davranış biçimleri geliştirmesini sağlamak amacıyla geleneksel pazarlama tekniklerinin kullanılmasıdır" (Bayraktaroğlu ve ilter, 2007).

Sosyal pazarlamanın geleneksel pazarlamadan en büyük farkı, bir hizmeti ya da malı satmak yerine bir düşüncenin, fikrin veya sosyal davranışın satılmasıdır. Ayrıca bu fikir ve düşüncelerin satılması ve kabul ettirilmesi ile tüketicilerin ve dolayısıyla toplumun belirli davranış biçimlerine yönlenmesi, belirli konularda inançlarında ve önyargılarında değişiklik yapılması amaçlanmaktadır (Bayraktaroğlu ve ilıter, 2007). Sosyal pazarlamanın en büyük amaçlarından biri de toplumda sosyal farkındalık yaratılmasıdır (Tek, 1999). Bu da gerek işletmeler gerekse kurumlar tarafından tasarlanan programların uygulanması ve denetlenmesi aracılığı ile gerçekleşmektedir.

Çeşitli araştırmacıların tanımları ışı̆ında sosyal pazarlama, tüketicilerin satın alma ve işletme tercih süreçlerinde sosyal sorumluluk anlayışını benimsemeleri ve toplumsal fayda sağlayacak ürünlere yönelmeleri maksadıyla onları bu tutum ve davranışlara yönlendirici fikirlerin pazarlanmasıdır. Sosyal pazarlama farklı kaynaklarda dava pazarlaması veya fikir pazarlaması olarak da anılmaktadır. Sosyal pazarlama, kâr amacı güdülmeden, toplumun yararına olan davranışların benimsenmesi, toplumsal sorunların çözümünde bireylerin de rol alabilmesi için onları yönlendirmek gibi herkesin menfaatine olan fikirlerin yaygınlaştırılması için kullanılan bir pazarlama yöntemidir (Kotler ve Armstrong, 2018). 
Andreasen (1995) sosyal pazarlamanın özelliklerini şu şekilde özetlemiştir:

- Sosyal pazarlama davranışsal amaca hizmet etmelidir.

- Kuruluş için kullanılan sermaye aralığının dar tutulması gerekmektedir.

- Sosyal pazarlamada tüketicilerin inanç ve değerleri göz ardı edilmemelidir.

- Benimsetmek istenen davranışın tüketiciye çekici gelmesi sağlanmalıdır.

- Sosyal pazarlamada uygun davranışlar tüketicinin gönülden yapması ile başarılı sayılabilir.

- Sosyal pazarlamada tüketici odaklı bir yaklaşım benimsendiği için araştırmalar sıklıkla ve sürekli yapılmalıdır.

- Pazar kitlesel olarak ele alınmak yerine çok net bir bölümleme yapılmalıdır.

\subsection{Sosyal Pazarlama Karması}

Kotler ve Lee (2008) sosyal pazarlama sürecini, yeni bir davranışın hedef kitleler üzerinde kabul edilmesi, davranışların hoş karşılanmadığı takdirde reddi, mevcut davranışın değiştirilmesi ya da mevcut ve hoşnutsuz olunan davranıştan uzaklaşma olarak açıklamışlardır. Bu sürecin işleyebilmesi ve hedef gruba yönlendirilecek amaçları uygulamaya koymak maksadıyla sosyal pazarlama karması araçlarının doğru ve tam olarak oluşturulması gerekmektedir.

Kotler ve Roberto (1989) yaptıkları çalışmada sosyal pazarlama karmasını aşağıdaki gibi oluşturmuşlardır:

- Mamul: Hizmetler, kalite, marka, garanti ve iade gibi hedef gruba yapılan teklifleri içerir.

- Fiyat: Hedef grubun, stres, toplum baskısı, kredileme ve haklar gibi katlandığı maliyetlerdir.

- Dağıtım: Hazırlama ve dağıtım hizmetleri ile sosyal mamulün hedef gruba iletilmesidir.

- Tanıtım: Reklâm, kişisel satış, satış geliştirme ve halkla ilişkiler faaliyetleri ile sosyal mamulün hedef gruba tanıtılmasıdır.

- Personel: Sosyal mamulün hedef gruba ulaştırılmasını sağlayan çalışanlardır.

- Sunuş: Sosyal mamulün kullanımına yönelik gözle görülebilir duyumsal elemanları ifade eder.

- Süreç: Hedef grubun sosyal mamulü tanıyıp kabul etmesine kadar geçen süreyi ifade eder.

Problemin tanımlanması ile başlayan sosyal pazarlama süreci söz konusu problemin çözümüne yönelik hedefin belirlenmesi, belirlenen hedefe yönelik pazarın seçilmesi, bu pazarda hitap edilecek tüketicilerin analiz edilmesi, sosyal pazarlama kampanyasının temelini oluşturacak kanalların analiz edilmesi, belirlenen sosyal pazarlama programlarının uygulanması ve son olarak da değerlendirme ile son bulur (Mert, 2012). Özellikle etkin bir tanıtım sayesinde hedef kitlenin herhangi bir faaliyet ya da ürüne yönlenmesi sağlanmalıdır. Buna ek olarak kamuoyunun/hedef kitlenin ikna edilmesi, bu sürecin en önemli tamamlayıcısıdır (Raghunathan ve Trope, 2002). Sosyal pazarlama faaliyetlerinin başarıya ulaşması için yalnızca işletmeler değil aynı zamanda diğer kurumlar ve kişiler de zaman, emek ve çaba harcamak zorundadırlar. Çünkü eski tutum ve davranışın yerine yenisinin oluşturulması süreci, sanıldığından daha zor bir süreçtir (Yıldırır, 2016).

\subsection{Sosyal Pazarlama Sürecinde Tüketici Davranışları}

Yapılan çalışmalar neticesinde bireylerin davranışlarına etki eden unsurlar arasında en önemli iki unsurun tutum ve niyet olduğu görülmüştür. Tutum ve niyet, kişileri gerçekleşen davranışa yönlendiren ve bu davranışı sergilemelerini sağlayan nedenlerden oluşmaktadır (Ajzen, 1985).

Tutum "öğrenilen, önceden hazırlığı yapılan bir eylem ve bir objeye doğru, olumlu veya olumsuz yönde sürekli bir eylemdir" şeklinde tanımlanabilir (Yanık, 2014). Tutumun, bireylerin davranışlarında bulunması gereken bir ön şart olduğu yapılan araştırmalarda da tespit edilmiştir (Ajzen, 1985; Ma, Anderson 
ve Streith, 2005; Linan ve Chen, 2009). Araştırmacılara göre tutum, çift taraflı etki veya değerlendirme neticesinde ölçülebilir. Tutumun temelinde tutarlılık yatmaktadır. Kişileri, objeleri, olayları sevme ya da sevmeme durumu tutumla açıklanabilir. Tutum diğer etmenlerin aksine değiştirilmesi zor bir yargıdır. Tutumları değiştirmek için birden fazla durumun değiştirilmesi gerekebilir. Söz konusu bu değişim çok zor gibi görünse de yüksek maliyetlerin harcanması sonucu verim elde edildiği de görülmüştür (Davis, 1989).

Kişinin davranışının temelinde yatan asıl belirleyici niyettir. Bilişsel uyumsuzluk teorisine göre, kişilerin davranışları ile niyeti arasında ortaya çıkan farklıık bir gerilim yaratmaktadır ve kişiler niyetleri ile davranışları arasında bir doğru orantı sağlayarak tutarlılık sergilemek isterler (Yılmaz ve Tümtürk, 2015). Kişilerin hayatları boyunca aldıkları rasyonel kararların hemen hemen hepsinde niyet ve davranış arasındaki ilişki önemli bir rol oynar (Kim vd., 2003). Aynı şekilde işletmeler de söz konusu hizmetleri kimlerin satın aldığı ya da almak istediği hakkında bilgi sahibi olmak isterler (Crespo ve Bosque, 2008; Çakır, 2012).

Sosyal pazarlama tüketici davranışının satın alma davranışı kısmını etkilemeye çalışıyor gibi görünse de satın alma kararında etkili olması sürecin başarılı bir şekilde işlemesi için daha verimli olacaktır. Sosyal pazarlamanın tüketici davranışları üzerinde etkili olması gereken en önemli husus, sebep olduğu davranış değişikliğinin sürekli olmasıdır.

\section{Literatür Taraması ve Hipotezlerin Oluşturulması}

Işletmelerin, sosyal pazarlama faaliyetinde bulunurken, tüketici üzerinde bırakacakları izlenimin söz konusu faaliyetlere yönelik tutum ve düşünceleri ne derecede etkileyeceği konularında araştırmalar yapması gerekmektedir. Sosyal pazarlama ve tüketici davranışları ile ilgili yapılan bazı çalışmalarda, işletmelerin uyguladığı sosyal pazarlama faaliyetlere yönelik tutumun satın alma niyetini etkilediği (Demirgüneş, 2015; Yapraklı, Noksan ve Ünalan, 2017; İzmir ve Turgut, 2019), tüketici nezdinde algılanan marka değerinin ve satın alma tercihlerinin olumlu yönde etkilendiği (Çakır ve Arslan, 2016; Yapraklı vd., 2017) tespit edilmiştir. Tüketicilerin sosyal pazarlama faaliyetlerine yönelik tutumları, çevresel zararları azaltma, çevreyi iyileştirme, yardıma muhtaçlara yardımda bulunma, kötü şartlarda çalışmalarına engel olma gibi konularda farklılık gösterebilir (Demirgüneş, 2015). Doğru planlanmış sosyal pazarlama faaliyetleri ile tüketicilerin tutumlarında olumlu etkiler yaratılarak belirtilen konularda etkileyici olmaları sağlanabilir. Literatürde yer alan ve belirtilen bulgulardan yola çıkarak aşağıdaki hipotez kurgulanmıştır.

\section{H1: Tüketicilerin tutumları ile satın alma niyetleri arasında anlamlı bir ilişki vardır.}

Tüketicilerin satın alma niyetleri, gerçekleşmesi planlanan davranışların tahmin edilmesi için en uygun araçtır (Carrington, Neville ve Whitwell 2010). Niyetler davranışların merkezi belirleyicisi olarak görülmektedir (David ve Rundle-Thiele, 2018). Yapılan çalışmalar, sosyal pazarlama faaliyetlerinin tüketicilerin satın alma niyetlerini olumlu yönde etkilediğini, göstermektedir (İzmir ve Turgut, 2019). Bazı çalışmalarda işletmelerin sosyal, toplumsal ya da çevre konularına duyarsız kalmalarının, tüketicilerin işletmeye karşı olumsuz tepkiler göstermesine sebep olabileceği ve etik satın alma niyeti ile gerçekleşen davranış arasında farklılık olabileceği belirtilmektedir (İzmir ve Turgut, 2019; Demirağ, 2020). Buna rağmen genel olarak konu ile ilgili yapılan çalışmalar sonucunda, sosyal pazarlama faaliyetlerinin işletmeye/markaya karşı davranışsal niyetler geliştirilmesini sağladığı belirlenmiştir (Yapraklı vd., 2017; Farrukh, Yazan, Imran, Shahzad ve Waheed, 2018). Literatürde yer alan ve belirtilen bulgulardan yola çıkarak aşağıdaki hipotez kurgulanmıştır.

\section{H2: Tüketicilerin tutumları ile gerçekleşen davranış arasında anlamlı bir ilişki vardır.}

İşletmelerin geliştirdikleri sosyal pazarlama stratejilerine yönelik tüketiciler duyarlılıklarını gerçekleşen satın alma davranışı ile göstermektedirler (Yapraklı vd., 2017; İzmir ve Turgut, 2019). Sosyal, toplumsal ya da çevre konularında duyarlı olmak tüketicilerin genel sorumluluğu olarak görülebilmektedir (Oğuz ve Bilgen, 2017). Yapılan çalışmalarda tüketicilerin sosyal pazarlama stratejileri ile bütünleşmiş işletmeleri tercih ettikleri, bu işletme ve markaları tavsiye ettikleri ve referans oldukları belirlenmiştir. Bilinçli tüketicilerin artması da sosyal pazarlama faaliyetlerine öncelik veren işletmelerin ve ürünlerinin tercih edilmesinde önemli bir faktör olarak görülmektedir (Manzano, Rivas ve Bonilla, 2012; Iftekhar, Ayub, Razzaq 
ve Aslam, 2013; Koçoğlu ve Koçoğlu, 2017). Literatürde yer alan ve belirtilen bulgulardan yola çıkarak aşağıdaki hipotez kurgulanmıştır.

$\boldsymbol{H}_{3}$ : Tüketicilerin satın alma niyetleri ile gerçekleşen davranış arasında anlamlı bir ilişki vardır.

Literatürde tüketicilerin kişisel özellikleri ile sosyal pazarlama faaliyetlerine karşı tutum, satın alma niyeti ve satın alma davranışı arasındaki ilişkileri inceleyen çalışmalarda genel olarak genç tüketicilerin diğer yaş gruplarına kıyasla (Koçoğlu ve Koçoğlu, 2017), kadınların erkeklere kıyasla (Koçoğlu ve Koçoğlu, 2017; Yılmaz Yaman, 2018; Aşıkoğlu, 2019), eğitim seviyesi yüksek tüketicilerin düşük olanlara kıyasla, evlilerin bekâr tüketicilere kıyasla sosyal, toplumsal ve çevre konularında daha duyarlı oldukları tespit edilmiştir. Ayrıca bazı çalışmalar üniversite öğrencilerinin sosyal pazarlama faaliyetlerine önem veren markaların ürünlerine ederinden daha fazla ücret ödeyeceklerini belirtmektedir (Onurlubaş ve Dinçer, 2016; Koçoğlu ve Koçoğlu, 2017; Yavuz ve Ünal, 2018). Literatürde yer alan ve belirtilen bulgulardan yola çıkarak aşağıdaki hipotez kurgulanmıştır.

$\boldsymbol{H}_{4}$ : Tüketicilerin cinsiyetlerine göre, sosyal pazarlama faaliyetlerine yönelik tutum, niyet ve davranışları arasında farklıık vardır.

$\boldsymbol{H}_{5}$ : Tüketicilerin yaşlarına göre, sosyal pazarlama faaliyetlerine yönelik tutum, niyet ve davranışları arasında farklılık vardır.

$\boldsymbol{H}_{6}$ : Tüketicilerin gelir durumlarına göre, sosyal pazarlama faaliyetlerine yönelik tutum, niyet ve davranışları arasında farklıık vardır.

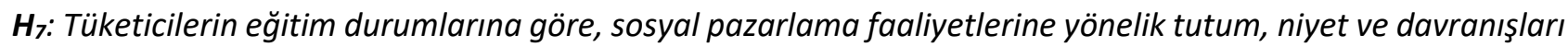
arasında farklıık vardır.

$\boldsymbol{H}_{8}$ : Tüketicilerin mesleklerine göre, sosyal pazarlama faaliyetlerine yönelik tutum, niyet ve davranışları arasında farklıık vardır.

\section{Metodoloji}

\subsection{Araştırmanın Amacı}

Bu çalışmanın amacı, işletmelerin sosyal pazarlama faaliyetlerinin, tüketicilerin tutum, satın alma niyeti ve davranışları üzerindeki etkisini incelemektir. Ayrıca demografik özelliklerine göre sosyal pazarlama faaliyetlerine karşı tutumları arasında bir farklılık olup olmadığının belirlenmesi de hedeflenmektedir.

\subsection{Araştırma Modeli}

İsletmelerin sosyal pazarlama faaliyetlerinin, tüketicilerin tutum ve satın alma niyetlerine etkisini incelemek ve niyet ile gerçekleşen davranış arasındaki ilişkiyi saptamak için Şekil 1'deki kavramsal model oluşturulmuştur. Model Ajzen'in Planlanmış Davranış Teorisinden esinlenerek kurulmuştur. Planlanmış Davranış Teorisinin değişkenlerinden biri olan öznel normların, bir davranışa yönelik sosyal baskıyı, kişilerin gösterecekleri davranışlara yönelik çevrenin algılamalarını ya da referans gruplar gibi diğer kurum ve kişilerin tüketicinin davranışları üzerindeki etkilerini/beklentilerini ifade etmesinin çalışma kapsamına alınmaması sebebiyle modelden çıkartılmasına karar verilmiştir (Erten, 2002; Kağıtçıbaşı ve Cemalıılar, 2015; Bozkurt ve Avcıkurt, 2019). Bunun yerine etkisinin ölçülmesi istenilen Demografik Değişkenler faktörü modele ilave edilmiştir ve Algılanan Davranışsal Kontrol faktörü modelden çıkarılmıştır. 
Şekil 1. Kavramsal Model

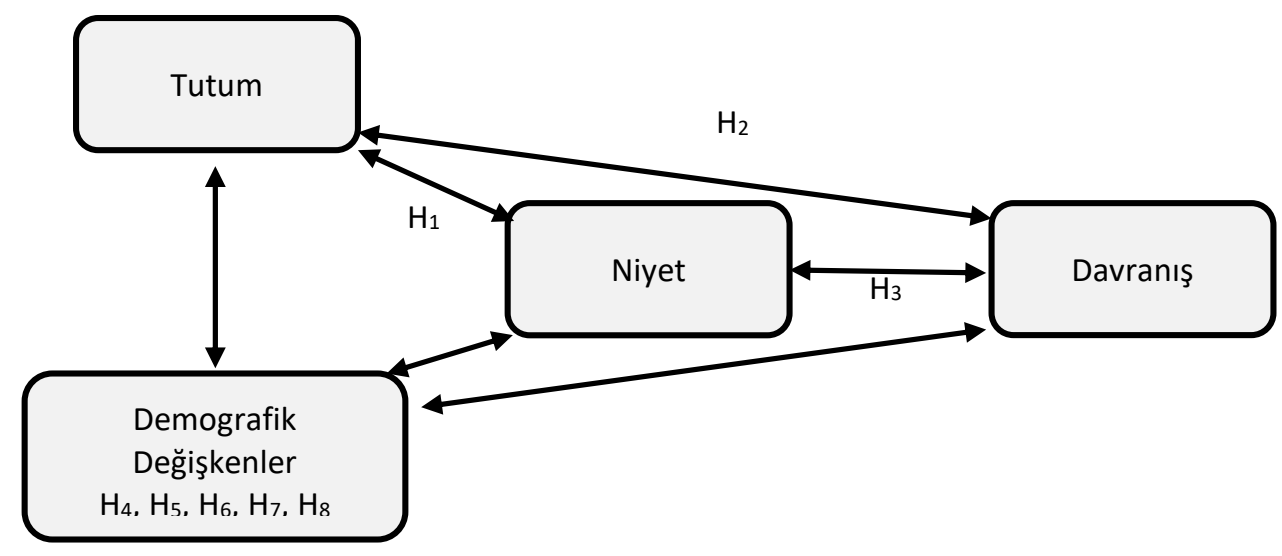

\subsection{Araştırma Örneklemi ve Yöntemi}

Çalışmanın ana kütlesini Türkiye sınırları içerisindeki tüketiciler oluşturmaktadır. Örneklemin seçiminde kolayda örnekleme yönteminin uygun bir yöntem olduğu değerlendirilmiştir. Analiz için kullanılan veriler "anket" tekniği ile online ve yüz yüze olarak 12 Kasım - 12 Aralık 2019 tarihleri arasında toplanmıştır. Ankette altı bölümde toplam 22 ifade araştırılmıştır. Hazırlanan sorulara "Kesinlikle Katılmıyorum, Katılmıyorum, Kararsızım, Katılıyorum ve Kesinlikle Katılıyorum" cevaplarından oluşan 5'li Likert tipi ifadeler sorulmuştur. Hazırlanan anket formu katılımcıların demografik özelliklerine yönelik ifadeler, işletmelerin sosyal pazarlama faaliyetlerine karşı tutum ve niyetlerine yönelik ifadeler ve tüketicilerin sosyal pazarlama faaliyetlerine ve bunu uygulayan işletme ve ürünlerine karşı satın alma davranışlarını ölçen ifadeler olmak üzere üç ana başlık altında toplanmaktadır. Ankette yer alan ifadeler Bayraktaroğlu ve ilter (2007), Cheng, Kotler ve Lee (2011) ve Akdoğan, Çoban ve Öztürk (2012)'ün çalışmalarından yararlanılarak geliştirilmiştir. Yapısal eşitlik modellemesinde örneklem yeter sayısını belirlemek için sabit bir yöntem olmamakla birlikte genellikle soru formunda değerlendirilen ifade sayısının on katı kadar bir örneklemin yeterli olduğu belirtilmektedir (Kline, 2011). 22 ifadeye yönelik 383 verinin elde edilmiş olması analiz için yeterli veriye ulaşıldığını göstermektedir.

Çalışmada belirlenen kavramsal modelin analiz edilmesi maksadıyla yapısal eşitlik modellemesi uygulanmıştır. Yapısal eşitlik modellemesi (YEM), genellikle sosyal bilimler araştırmalarında kullanılan ve sürekli, sıralı veya kategorik çok sayıda değişken arasındaki ilişkiyi eş zamanlı olarak ve ölçme hatalarını da modelleyerek inceleyebilen bir istatistiksel analiz yöntemidir (Kline, 2011; Tabachnick ve Fidell, 2013). Söz konusu model ve modele yönelik elde edilen veriler SPSS 23.00 ve AMOS 24 paket programları ile analiz edilmiştir.

\section{Analiz ve Bulgular}

\subsection{Katılımcıların Demografik Özellikleri}

Demografik değişkenlere yönelik bulgular Tablo 1'de sunulmuştur. Tablo 1 incelendiğinde; \%56,4 ile kadınların, \%61,3 ile 26-35 yaş arası katılımcıların, \%55,1 ile kamu çalışanlarının, \%63,4 ile lisansüstü öğrenim durumuna sahip katılımcıların ve $\% 48,8$ ile $3000-4500$ TL arası gelire sahip tüketicilerin çoğunlukta oldukları görülmektedir. 
Tablo 1. Demografik Değişkenler

\begin{tabular}{llcc}
\hline Değişken & & Frekans & $\%$ \\
\hline \multirow{2}{*}{ Cinsiyet } & Kadın & 216 & 56,4 \\
& Erkek & 167 & 43,6 \\
\hline \multirow{3}{*}{ Yaş } & 25 ve altı & 116 & 30,3 \\
& $26-35$ & 235 & 61,4 \\
& $36-45$ & 16 & 4,2 \\
& 46 ve üstü & 16 & 4,2 \\
\hline \multirow{3}{*}{ Meslek } & Çalışmıor & 44 & 11,5 \\
& Öğrenci & 40 & 10,4 \\
& Özel Sektör & 88 & 23,0 \\
Eğitim Durumu & Kamu Çalışanı & 211 & 55,1 \\
& İlköğretim & 8 & 2,1 \\
& Üniversite & 132 & 34,5 \\
& Lisansüstü & 243 & 63,4 \\
\hline \multirow{3}{*}{ Gelir Durumu } & 0-1500 TL & 104 & 27,2 \\
& $1501-3000$ TL & 48 & 12,5 \\
& 3001-4500 TL & 187 & 48,8 \\
& 4500 TL ve üstü & 44 & 11,5 \\
\hline
\end{tabular}

\section{2. Ölçeklerin Güvenirliği}

Ölçeklerin güvenilirliğini saptamak maksadıyla Cronbach's alpha değerinden faydalanılmıştır. Tüm faktörler için belirlenen Cronbach's alpha değerleri Tablo 2'de sunulmuştur. Güvenilirlik test sonuçları incelendiğinde Cronbach's alpha değeri \%70'in altında olan değer olmadığı ve ölçeğin iyi seviyede güvenilir olduğu görülmüştür. Hatcher (1994)'a göre, 0,50'nin üzerindeki alpha değerleri sosyal bilimler araştırmalarında yeterli sayılırken, 0,70 ve üzeri önerilmekte ve 0,80 ve üzeri arzu edilmektedir.

Tablo 2. Güvenilirlik Test Sonuçları

\begin{tabular}{lcc}
\hline Ölçek & Madde Sayısı & Cronbach's Alpha \\
\hline Tutum (T) & 5 & 0,861 \\
\hline Niyet (N) & 4 & 0,827 \\
\hline Davranış (D) & 3 & 0,744 \\
\hline
\end{tabular}

\subsection{Faktör Analizi}

Faktör analizi, birden fazla değişkenin bir araya getirilmesi ile oluşturulan yeni faktör veya boyutların bulunmasını ya da keşfedilmesini sağlayan çok değişkenli bir istatistikî analiz yöntemidir (Büyüköztürk, 2002).

\subsubsection{Keşfedici Faktör Analizi}

Gizil ve gözlenen değişkenler arasındaki ilişkinin ve buna istinaden değişkenlerin faktörlerle bağlantısını tespit eden analiz yöntemine keşfedici faktör analizi denilmektedir. Faktörlerin minimize edilmesi ve değişkenlerin birden fazla faktör altında toplanmasının önüne geçilerek analize olumsuz etki yaratmaması için değişkenler arasındaki kovaryansa bakılmaktadır (Hair, Black ve Babin, 2010).

Faktör yükleri hangi ifadenin hangi faktörün altında yer alması gerektiğini gösteren değerlerdir. Genellikle 0,45 üzerindeki faktör yüklerinin analiz için yeterli olduğu değerlendirilmektedir (Moore ve Benbasat, 1991). Çalışmada yapılan faktör analizine göre belirlenen 3 faktörün altında 12 ifade Tablo 3'te gösterilen faktör yükleri ile yer almıştır. 
Tablo 3. Faktör Analizi Sonuçları

\begin{tabular}{|c|c|c|c|}
\hline & $T$ & $\mathrm{~N}$ & $\mathrm{D}$ \\
\hline T1 & 0,905 & & \\
\hline $\mathrm{T} 2$ & 0,785 & & \\
\hline T3 & 0,678 & & \\
\hline T4 & 0,865 & & \\
\hline T5 & 0,485 & & \\
\hline N1 & & 0,539 & \\
\hline N2 & & 0,778 & \\
\hline N3 & & 0,905 & \\
\hline N4 & & 0,542 & \\
\hline D1 & & & 0,649 \\
\hline D2 & & & 0,870 \\
\hline D3 & & & 0,511 \\
\hline Özd.* & 6,127 & 1,337 & 0,863 \\
\hline $\mathrm{AV}^{* *}$ & 51,057 & 11,138 & 7,191 \\
\hline KMO Testi & ,880 & & \\
\hline \multicolumn{4}{|c|}{ Bartlett Küresellik Testi } \\
\hline
\end{tabular}

\subsubsection{Doğrulayıcı Faktör Analizi}

Keşfedici faktör analizinde elde edilen sonuçlarda her ifadenin tahmin edilen faktörün altında ya da birden fazla faktörün altında yer aldığı görülebilir. Bu durumda doğrulayıcı faktör analizi yapılarak faktörler arasındaki ilişkilere bir çözüm bulmak amaçlanır. Doğrulayıcı faktör analizi (DFA), herhangi bir karışıklığı ve sınırlamaları aşmak adına gözlenen ve örtük değişkenler arasındaki ilişkileri istatistiksel olarak test ederek duruma bir çözüm sunmayı amaçlar. Doğrulayıcı faktör analizi, araştırmada kullanılan maddelerin hangi faktörler altında toplandığının ve araştırmacı tarafından kontrol altında olduğunun bilinmesi durumlarında kullanılır. Doğrulayıcı faktör analizi, yapısal eşitlik modellemesi öncesinde belirlenen hipotezlerin ve kurulan modelin mantık ve gözlenen ölçümleri doğrultusunda uygulanır (Hair, Black ve Babin, 2010). Doğrulayıcı faktör analizi uyum indeksleri Tablo 4'te sunulmuştur.

Tablo 4. Doğrulayıcı Faktör Analizine Ilişsin Uyum İstatistikleri

\begin{tabular}{lccc}
\hline Uyum İndeksi & İyi Uyum & $\begin{array}{c}\text { Kabul Edilebilir } \\
\text { Uyum }\end{array}$ & $\begin{array}{c}\text { Ulaşılan } \\
\text { Değerler }\end{array}$ \\
\hline$\chi 2 / \mathrm{df}$ & $\leq 2$ & $\leq 4-5$ & 3,457 \\
\hline RMSEA & $\leq 0,05$ & $0,06-0,08$ & 0,080 \\
\hline RMR & $\leq 0,05$ & $0,06-, 08$ & 0,033 \\
\hline Goodness of Fit Index (GFI) & $\geq 0,90$ & $0,85-0,90$ & 0,948 \\
\hline Normed Fit Index (NFI) & $\geq 0,90$ & $0,85-0,90$ & 0,952 \\
\hline Incremental Fit Index (IFI) & $\geq 0,95$ & $0,94-0,90$ & 0,966 \\
\hline Comperative FIt Index (CFI) & $\geq 0,95$ & $\geq 0,90$ & 0,965 \\
\hline
\end{tabular}

Kaynak: Meydan ve Şeşen (2011); Çokluk, Şekercioğlu ve Büyüköztürk (2014).

Doğrulayıcı faktör analizine ilişkin uyum değerleri incelendiğinde, $\chi 2$ /df ve RMSEA değerlerinin kabul edilebilir uyum aralığında olduğu; RMR, GFI, NFI, IFI ve CFI degerlerinin ise iyi uyum seviyesinde olduğu tespit edilmiştir. Bu sonuçlar önerilen modelin ve analiz verisinin istatistiksel olarak uygunluğunu ispat etmektedir.

Çalışmalarda ele alınan ve gözlenen değişkenlerin, gizil birer temsilci olup olmadığını anlayabilmek için birleşim geçerliliğine bakılması gerekmektedir. Birleşim geçerliliği, gizil değişken ile gözlenen değişkenlerin iliş̧i derecesidir (Hair vd., 2010). Birleşim geçerliliği iç̧in CR (Composite Reliability) değerinin 0,70'in üzerinde, AVE (Average Variance Extracted) değerinin 0,50'nin üzerinde ve MSV (Maximum Shared 
Variance) değerinin de AVE değerinden küçük olması gerekmektedir. Modeli oluşturan değişkenlerin birleşim geçerlilik değerleri Tablo 5'te sunulmuştur.

Tablo 5. Birleşim Geçerlilik Değerleri

\begin{tabular}{cccc}
\hline & CR & AVE & MSV \\
\hline $\mathrm{T}$ & 0,843 & 0,525 & 0,126 \\
\hline $\mathrm{N}$ & 0,818 & 0,534 & 0,126 \\
\hline $\mathrm{D}$ & 0,850 & 0,675 & 0,219 \\
\hline
\end{tabular}

Ki-kare testinin sonucu Tablo 6'daki değerlere göre kabul edilebilir aralıkta ve anlamlı çıkmıştır. Bu sonuca göre gözlenen faktörler arasında istatistiksel olarak anlamlı bir farklılık olduğu anlaşılmaktadır. Analiz sonucuna göre GFI ve NFI değerleri iyi uyum seviyesinde, IFI ve CFI değerleri kabul edilebilir uyum seviyesinde, RMSEA değeri ise kabul edilebilir uyum seviyesinden yüksek bir değerde çıkmıştır. Uyum indekslerine yönelik faktör yükleri Tablo 5'te sunulmuştur.

Tablo 6. Doğrulayıcı Faktör Analizi Sonuçları

\begin{tabular}{lccc}
\hline & T & N & D \\
\hline T1 & 0,725 & & \\
T2 & 0,792 & & \\
T3 & 0,685 & & \\
T4 & 0,529 & & \\
T5 & 0,799 & & \\
\hline N1 & & 0,837 & \\
N2 & 0,651 & \\
N3 & 0,590 & \\
N4 & & 0,816 & 0,870 \\
\hline D1 & & & 0,437 \\
D2 & & & 0,982 \\
D3 & & & p: 0,000 \\
\hline Bartlett Küresellik Testi & df: 66 & $\chi 2: 2751,252$ & \\
\hline
\end{tabular}

\subsection{Yapısal Eşitlik Analizi}

AMOS paket programı ile yapılan analiz neticesinde elde edilen model parametre istatistikleri ve bu sonuçların yorumlanması sonucu ulaşılan bulgular analiz bölümünde sunulmuştur.

Uyum indekslerinin araştırılmasından sonra gelen aşamada modelin parametreleri incelenmiştir. Model parametre tahmin ve istatistiklerinde özellikle bakılması gereken hususlar; $C R$, standart sapma, $\mathrm{R}^{2}$ ve $p$ değeridir. Parametre tahmin ve istatistikleri Tablo 7'de sunulmuştur.

Tablo 6'da da görüldüğü gibi araştırma modelinin üç faktörünün ( $T, N$ ve $D$ ) de belirleyicilik düzeylerinin anlamlı olduğu anlaşılmıştır $(p<0,001)$. Tutum değişkeni incelendiğinde, değişkenliği en çok "Sağlık, spor, kültür, çevre, enerji gibi konularda firmaların kitle iletişim araçları vasıtasıyla yaptıkları faaliyetler ve sponsorluklar sosyal konulara duyarlılığımı etkiler" ifadesi açıklamaktadır $\left(R^{2}=0,69\right)$. En az ise "Alışveriş yaparken satın aldığım ürünün üreticisinin sosyal sorumluluk kampanyaları gerçekleştirip gerçekleştirmediğine bakarım" ifadesi $\left(R^{2}=0,24\right)$ açıklamaktadır. Bu değişkene ait standart değerler uygun seviyededir ve t değeri de anlamlıdır. 
Tablo 7. Model Parametre İstatistikleri

\begin{tabular}{|c|c|c|c|c|c|}
\hline \multicolumn{6}{|c|}{ Değişkenler } \\
\hline Tutum & Tahmin & t-değeri (CR) & Standart Sapma & $\mathrm{R}^{2}$ & $p$ \\
\hline T1 & 1,056 & 14,025 & 0,075 & 0,47 & \\
\hline $\mathrm{T} 2$ & 1,023 & 13,577 & 0,075 & 0,56 & $* * *$ \\
\hline T3 & 0,977 & 13,368 & 0,073 & 0,41 & $* * *$ \\
\hline T4 & 0,747 & 9,155 & 0,082 & 0,24 & $* * *$ \\
\hline T5 & 1,000 & & & 0,69 & \\
\hline Niyet & Tahmin & t-değeri (CR) & Standart Sapma & $\mathrm{R}^{2}$ & $p$ \\
\hline N1 & 1,033 & 19,554 & 0,053 & 0,72 & $* * *$ \\
\hline N2 & 0,639 & 12,177 & 0,053 & 0,42 & $* * *$ \\
\hline N3 & 0,666 & 10,866 & 0,061 & 0,34 & $* * *$ \\
\hline N4 & 1,000 & & & 0,66 & \\
\hline Davranış & Tahmin & t-değeri (CR) & Standart Sapma & $\mathrm{R}^{2}$ & $p$ \\
\hline D1 & 1,000 & & & 0,88 & $* * *$ \\
\hline D2 & 0,602 & 7,134 & 0,084 & 0,20 & $* * *$ \\
\hline D3 & 1,218 & 18,703 & 0,065 & 0,96 & $* * *$ \\
\hline
\end{tabular}

${ }_{* * *} \mathrm{p}<0,001$ belirleyicilik düzeyinde anlamına gelmektedir.

Niyet değişkeni incelendiğinde, değişkenliği en çok "işletmelerin sosyal fayda yaratması tercihlerimi etkiler" ifadesi açıklarken $\left(R^{2}=0,72\right)$, en az ise "işletmelerin bir sivil toplum kuruluşu ile birlikte çalışmasının kampanyanın etkinliğini arttıracağına inanıyorum" ifadesi $\left(R^{2}=0,34\right)$ açıklamıştır. Bu değişkene ait standart değerler uygun seviyededir ve $t$ değeri de anlamlıdır.

Davranış değişkeni incelendiğinde, değişkenliği en çok "Sosyal pazarlama faaliyetleri, işletmeyi tekrar tercih etmem için önemli bir etmendir" ifadesi açıklarken $\left(R^{2}=0,96\right)$, en az ise "Sosyal konulara yönelik çeşitli çalışmalar yapmak ve bütçe ayırmak, işletmeler için yasal bir zorunluluk olmalıdır" ifadesi $\left(R^{2}=0,20\right)$ açıklamıştır. Bu değişkene ait standart değerler uygun seviyededir ve t değeri de anlamlıdır.

Kavramsal modelin testi sonucu elde edilen uyum indekslerinin analiz için yeterli aralıkta çıkması ile faktörler arasındaki ilişkilerin tespiti aşamasına gelinmiştir. Yapılan analiz neticesinde elde edilen $t$ değerleri Şekil 2'de gösterilmiştir.

Şekil 2. Yapısal Model t Değerleri

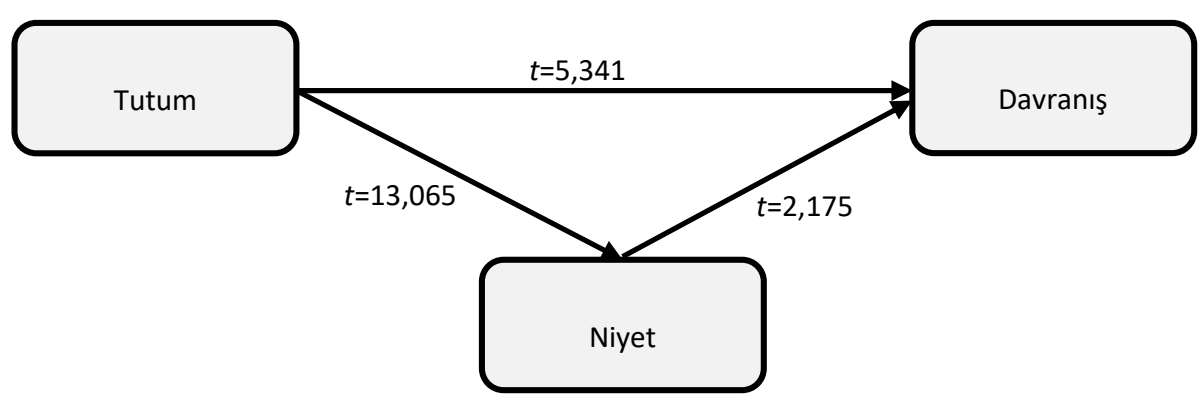

Tablo 8. Model Kapsamında Oluşturulan Yapısal Eşitlik Modeli Katsayıları

\begin{tabular}{|c|c|c|c|c|c|c|c|}
\hline Hipotez & & & & Tahmin & S.H. & $p$ & Kabul/Ret \\
\hline $\mathrm{H}_{1}$ & $\mathrm{~T}$ & $-->$ & $\mathrm{N}$ & 0,868 & 0,066 & $* * *$ & Kabul \\
\hline $\mathrm{H}_{2}$ & $\mathrm{~T}$ & $-->$ & $\mathrm{D}$ & 0,630 & 0,118 & $* * *$ & Kabul \\
\hline $\mathrm{H}_{3}$ & $\mathrm{~N}$ & $-->$ & D & 0,232 & 0,107 & $0,030 * *$ & Kabul \\
\hline
\end{tabular}


Tablo 8 incelendiğinde, tüketicilerin sosyal pazarlama faaliyetlerine yönelik tutum, niyet ve satın alma davranışlarını etkileyen faktörler ve bu faktörlerin birbiri ile etkileşimi görülmektedir. Çalışmanın başında belirlenen ve tutum, niyet ve davranış arasındaki ilişkiye yönelik kurulmuş olan üç hipotez de kabul edilmiştir.

Hipotez 1'in kabul edilmesi, işletmelerin doğru ve etkili sosyal pazarlama faaliyetlerine yönelik tüketicilerin tutumlarının satın alma niyetlerine olumlu yönde bir etkisinin olacağını göstermektedir. Tüketicilerin sosyal pazarlama faaliyetlerine yönelik tutumları, çevresel, toplumsal ve sosyal anlamda destekleyebilecekleri kampanyalara kayıtsız kalmayacaklarını göstermektedir.

Hipotez 2'nin kabul edilmesi ile sosyal, toplumsal ya da çevresel konularda dürüst ve kararlı stratejiler izleyen işletmelerin, sosyal farkındalığı yüksek tüketiciler tarafından daha fazla tercih edildiği anlaşılmaktadır. Tüketiciler işletmeler ve sosyal pazarlama faaliyetleri ile ilgili kuşkuya kapıldıklarında, her ne kadar sosyal faaliyetleri destekleme niyetinde olsalar da, bu niyetlerini davranışa dönüştürmemektedirler.

Kabul edilen Hipotez 3'e göre, tüketicilerin genel bir sorumluluk olarak algıladıkları sosyal duyarlılık, işletmelerin etkin sosyal pazarlama stratejileri ile desteklendiğinde ilerleme kaydedilebilmektedir. İşletmeler tüketicilerin bilinçlenmesini sağladığında hem sosyal konularda fayda yaratmış hem de sadık müşteri elde etme konularında başarı sağlamış olmaktadırlar.

\subsection{T-testi ve ANOVA Analizleri}

Demografik özelliklere göre tüketicilerin sosyal pazarlama faaliyetlerine yönelik tutum, niyet ve davranışları arasında istatistiksel olarak anlamlı farklıııklar olup olmadığına ilişkin hipotezleri test etmek için bağımsız gruplar t-testi ve tek yönlü varyans analizi (ANOVA) uygulanmıştır.

Tablo 9. Cinsiyet ve Tüketici Davranışları Ilişkilerinin Betimleyici İstatistikleri

\begin{tabular}{lllllllc}
\hline & Cinsiyet & $\mathrm{N}$ & $\mathrm{Ss}$ & $\mathrm{F}$ & $\mathrm{t}$ & $\mathrm{p}$ & Ort. \\
\hline \multirow{2}{*}{ Tutum } & Kadın & 216 & 0,079 & \multirow{2}{*}{6,478} & 7,600 & 0,000 & 3,692 \\
& Erkek & 167 & 0,081 & & 7,446 & 0,000 & 3,089 \\
\hline \multirow{2}{*}{ Niyet } & Kadın & 216 & 0,071 & \multirow{2}{*}{0,314} & 3,437 & 0,001 & 4,097 \\
& Erkek & 167 & 0,071 & & 3,434 & 0,001 & 3,851 \\
\hline \multirow{2}{*}{ Davranış } & Kadın & 216 & 0,080 & \multirow{2}{*}{9,909} & 3,046 & 0,002 & 3,925 \\
& Erkek & 167 & 0,079 & & 3,006 & 0,003 & 3,688 \\
\hline \hline
\end{tabular}

Tablo 9'daki verilere göre $\mathrm{pT}=0,000, \mathrm{pN}=0,001$ ve $\mathrm{pD}=0,003<0,05$ olduğundan farklı cinsiyete sahip katılımcıların sosyal pazarlama faaliyetlerine yönelik tutum, niyet ve davranışları farklı yönde eğilim gösterdiği anlaşılmıştır. Yani cinsiyete göre tüketicilerin sosyal pazarlama faaliyetlerine yönelik davranışları arasında anlamlı bir farklııık bulunmaktadır.

Tablo 10. Yaş ve Tüketici Davranışlarına İlişkin Varyans Analiz Sonucu

\begin{tabular}{llccccc}
\hline \multirow{4}{*}{ Tutum } & Varyans Kaynakları & KT & Sd. & KO & F & p \\
& Gruplararası & 23,685 & 3 & 7,895 & & \\
& Grup içi (hata) & 236,256 & 379 & 0,623 & 12,665 & 0,000 \\
& Toplam & 259,941 & 382 & & & \\
\multirow{3}{*}{ Niyet } & Gruplararası & 1,855 & 3 & 0,618 & & \\
& Grup içi (hata) & 186,796 & 379 & 0,493 & 1,254 & 0,290 \\
& Toplam & 188,651 & 382 & & & \\
\hline \multirow{3}{*}{ Davranış } & Gruplararası & 3,046 & 3 & 1,015 & & \\
& Grup içi (hata) & 219,992 & 379 & 0,580 & 1,749 & 0,157 \\
& Toplam & 223,038 & 382 & & & \\
\hline
\end{tabular}

KT: Kareler Toplamı, Sd: Serbestlik Derecesi, KO: Kareler Ortalaması. 
Tablo 10 'da görüldüğg̈ gibi tutumun gruplar arasında anlamlı bir şekilde farklılaştığı saptanmış (F: $12,665 ; p<0,05)$ ancak niyet $(F: 1,254 ; p>0,05)$ ve davranışta ( $F: 1,749 ; p>0,05)$ anlamlı bir farklılık tespit edilmemiştir. Tüketicilerin sosyal pazarlama faaliyetlerine yönelik tutumlarında gruplar arasındaki bu farklıı̆ı̆ı kaynağını belirlemek için post-hoc test istatistiği belirlenmiştir.

Tablo 11. Yaş ve Tutum Çoklu Karşılaştırma Verileri

\begin{tabular}{|c|c|c|c|c|c|c|}
\hline & (ı) Yaş & $\mathrm{N}$ & (j) Yaş & Ort. Farkı (ı-j) & Std. Hata & $\mathrm{p}$ \\
\hline \multirow{6}{*}{ Tutum } & \multirow{2}{*}{25 ve altı } & 235 & $26-35$ arası & $0,45326 *$ & 0,08971 & 0,000 \\
\hline & & 32 & 36 ve üstü & $0,77241 *$ & 0,15787 & 0,000 \\
\hline & \multirow{2}{*}{$26-35$ arası } & 116 & 25 ve altı & $-0,45326^{*}$ & 0,08971 & 0,000 \\
\hline & & 32 & 36 ve üstü & 0,31915 & 0,14898 & 0,083 \\
\hline & \multirow{2}{*}{36 ve üstü } & 116 & 25 ve altı & $-0,77241^{*}$ & 0,15787 & 0,000 \\
\hline & & 235 & 26-35 arası & $-0,31915$ & 0,14898 & 0,083 \\
\hline
\end{tabular}

Söz konusu farklılığı yaratan grup ya da gruplar için belirlenmiş olan çoklu karşılaştırma verileri Tablo 11 'de sunulmuştur. Tablo 11 'deki verilere göre 25 yaş ve altındaki tüketicilerin sosyal pazarlama faaliyelerine yönelik tutumları diğer yaş grupları ile farklılık göstermektedir.

Tablo 12. Gelir Durumu ve Tüketici Davranışlarına İlişkin Varyans Analiz Sonucu

\begin{tabular}{llccccc}
\hline \multirow{4}{*}{ Tutum } & Varyans Kaynakları & KT & Sd. & KO & F & p \\
\hline \multirow{4}{*}{ Niyet } & Gruplararası & 6,725 & 3 & 2,242 & & \\
& Grup içi (hata) & 253,216 & 379 & 0,668 & 3,335 & 0,019 \\
& Toplam & 259,941 & 382 & & & \\
& Gruplararası & 3,574 & 3 & 1,191 & & \\
& Grup içi (hata) & 185,077 & 379 & 0,488 & 2,440 & 0,064 \\
& Toplam & 188,651 & 382 & & & \\
\multirow{2}{*}{ Davranış } & Gruplararası içi (hata) & 5,663 & 3 & 1,888 & & \\
& Toplam & 217,375 & 379 & 0,574 & 3,291 & 0,021 \\
& & 223,038 & 382 & & & \\
\hline
\end{tabular}

Tablo 12'de görüldüğü gibi tutum $(F: 3,335 ; p<0,05)$ ve davranışın $(F: 3,291 ; p<0,05)$ gruplar arasında anlamlı bir şekilde farklılaştığı saptanmış ancak niyette ( $F: 2,440 ; p>0,05)$ anlamlı bir farklılık tespit edilmemiştir. Tüketicilerin sosyal pazarlama faaliyetlerine yönelik tutum ve davranışlarında gruplar arasındaki bu farklılığın kaynağını belirlemek için post-hoc test istatistiği belirlenmiştir.

Tablo 13. Gelir Durumu ve Tutum, Davranış Çoklu Karşılaştırma Verileri

\begin{tabular}{|c|c|c|c|c|c|c|}
\hline & (।) Gelir & $N$ & (j) Gelir & $\begin{array}{l}\text { Ort. Farkı } \\
\qquad(ı-j)\end{array}$ & Std.Hata & $p$ \\
\hline \multirow{9}{*}{ Tutum } & \multirow{3}{*}{$0-1500$} & 48 & $1501-3000$ & 0,16667 & 0,14263 & 0,647 \\
\hline & & 187 & $3001-4500$ & 0,19893 & 0,09998 & 0,194 \\
\hline & & 44 & 4500 ve üstü & $0,45455^{*}$ & 0,14700 & 0,011 \\
\hline & \multirow{3}{*}{$1501-3000$} & 104 & $0-1500$ & $-0,16667$ & 0,14263 & 0,647 \\
\hline & & 187 & $3001-4500$ & 0,03226 & 0,13226 & 0,995 \\
\hline & & 44 & 4500 ve üstü & 0,28788 & 0,17060 & 0,332 \\
\hline & \multirow{3}{*}{$3000-4500$} & 104 & $0-1500$ & $-0,19893$ & 0,09998 & 0,194 \\
\hline & & 48 & $1501-3000$ & $-0,03226$ & 0,13226 & 0,995 \\
\hline & & 44 & 4500 ve üstü & 0,25561 & 0,13696 & 0,244 \\
\hline
\end{tabular}


Tablo 13. Gelir Durumu ve Tutum, Davranış Çoklu Karşılaştırma Verileri (Devamı)

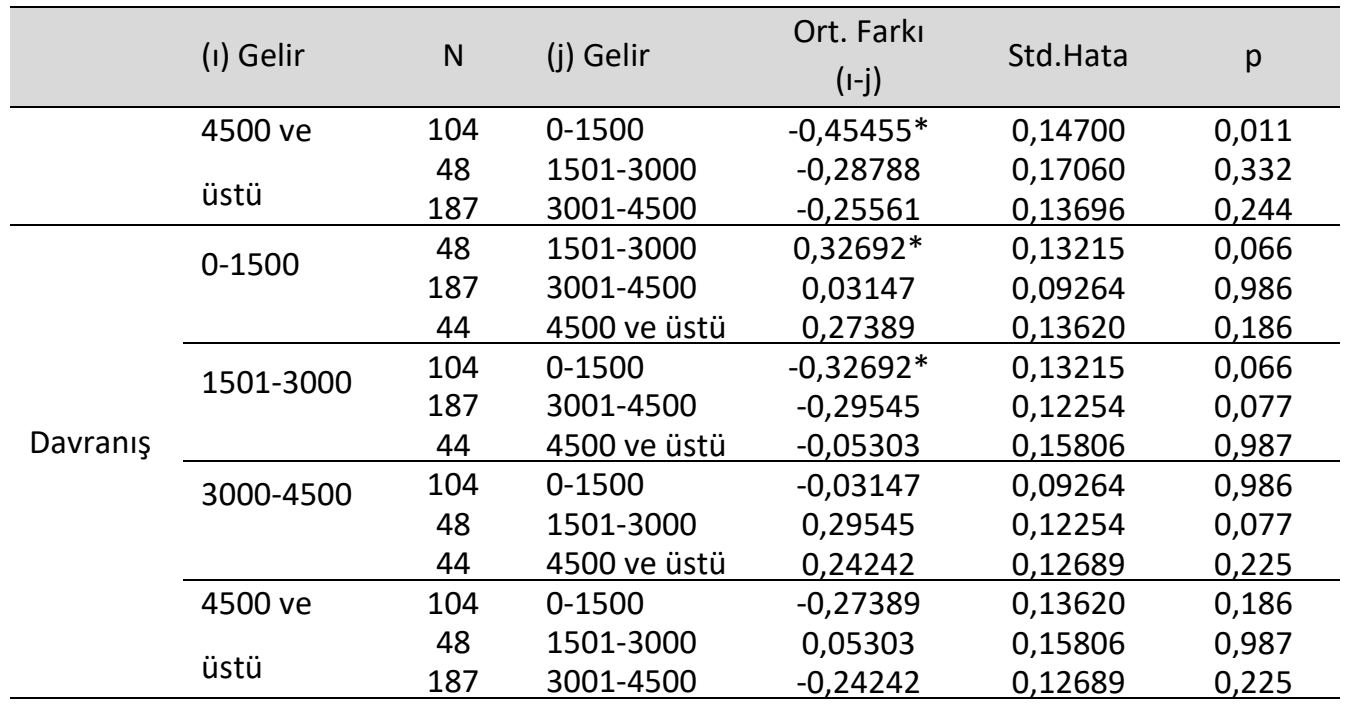

Söz konusu farklııı̆ı yaratan grup ya da gruplar için belirlenmiş olan çoklu karşılaştırma verileri Tablo $13^{\prime}$ de sunulmuştur. Tablo $12^{\prime}$ deki verilere göre geliri 4500 TL ve üstü olan tüketicilerin sosyal pazarlama faaliyelerine yönelik tutumları 0-1500 TL arasındaki tüketiciler ile farklılık göstermektedir. Ayrıca geliri 0-1500 TL arasında olan tüketicilerin sosyal pazarlama faaliyelerine yönelik satın alma davranışları, diğer gelir grubundaki tüketicilerin davranışları ile farklılık göstermektedir.

Tablo 14. Eğitim Durumu ve Tüketici Davranışlarına Illişkin Varyans Analiz Sonucu

\begin{tabular}{|c|c|c|c|c|c|c|}
\hline & Varyans Kaynakları & $\mathrm{KT}$ & Sd. & KO & $\mathrm{F}$ & $p$ \\
\hline & Gruplararası & 16,636 & 2 & 8,318 & & \\
\hline \multirow[t]{3}{*}{ Tutum } & Grup içi (hata) & 243,304 & 380 & 0,640 & 12,991 & 0,000 \\
\hline & Toplam & 259,941 & 382 & & & \\
\hline & Gruplararası & 2,332 & 2 & 1,166 & & \\
\hline \multirow[t]{3}{*}{ Niyet } & Grup içi (hata) & 186,319 & 380 & 0,490 & 2,378 & 0,094 \\
\hline & Toplam & 188,651 & 382 & & & \\
\hline & Gruplararası & 3,624 & 2 & 1,812 & & \\
\hline \multirow[t]{2}{*}{ Davranış } & Grup içi (hata) & 219,414 & 380 & 0,577 & 3,138 & 0,044 \\
\hline & Toplam & 223,038 & 382 & & & \\
\hline
\end{tabular}

Tablo 14' de görüldüğü gibi tutum (F: 12,991; $p<0,05)$ ve davranışın ( $F: 3,138 ; p<0,05)$ gruplar arasında anlamlı bir şekilde farklılaştığı saptanmış ancak niyette ( $F: 2,378 ; p>0,05)$ anlamlı bir farklılık tespit edilmemiştir. Tüketicilerin sosyal pazarlama faaliyetlerine yönelik tutum ve davranışlarında gruplar arasındaki bu farklılı̆̆ın kaynağını belirlemek için post-hoc test istatistiği belirlenmiştir.

Tablo 15. Eğitim Durumu ve Tutum, Niyet, Davranış Çoklu Karşılaştırma Verileri

\begin{tabular}{llclccc}
\hline \multirow{4}{*}{$\begin{array}{l}\text { Öğrenim } \\
(\text { । })\end{array}$} & $\mathrm{N}$ & $\begin{array}{l}\text { Öğrenim } \\
(\mathrm{j})\end{array}$ & $\begin{array}{c}\text { Ort. Farkı } \\
(\mathrm{I-j})\end{array}$ & Std.Hata & $\mathrm{p}$ \\
\hline \multirow{3}{*}{ Tutum } & ilköğretim & 132 & Üniversite & $-0,99091^{*}$ & 0,29135 & 0,002 \\
& & 243 & Lisansüstü & $-0,61193$ & 0,28752 & 0,086 \\
\cline { 2 - 7 } & Üniversite & 8 & ilköğretim & $0,99091^{*}$ & 0,29135 & 0,002 \\
& 243 & Lisansüstü & $0,37897^{*}$ & 0,08652 & 0,000 \\
\hline
\end{tabular}


Tablo 15. Eğitim Durumu ve Tutum, Niyet, Davranış Çoklu Karşılaştırma Verileri (Devamı)

\begin{tabular}{|c|c|c|c|c|c|c|}
\hline & $\begin{array}{l}\text { Öğrenim } \\
\text { (।) }\end{array}$ & $\mathrm{N}$ & $\begin{array}{l}\text { Öğrenim } \\
\text { (j) }\end{array}$ & $\begin{array}{c}\text { Ort. Farkı } \\
(\mathrm{I}-\mathrm{j})\end{array}$ & Std.Hata & $p$ \\
\hline & Lisansüstü & 8 & İlköğretim & 0,61193 & 0,28752 & 0,086 \\
\hline & & 132 & Üniversite & $-0,37897^{*}$ & 0,08652 & 0,000 \\
\hline \multirow{6}{*}{ Davranış } & İlköğretim & 132 & Üniversite & 0,23737 & 0,27668 & 0,667 \\
\hline & & 243 & Lisansüstü & 0,41358 & 0,27304 & 0,285 \\
\hline & Üniversite & 8 & İlköğretim & $-0,23737$ & 0,27668 & 0,667 \\
\hline & & 243 & Lisansüstü & $0,17621^{*}$ & 0,08216 & 0,082 \\
\hline & Lisansüstü & 8 & İlköğretim & $-0,41358$ & 0,27304 & 0,285 \\
\hline & & 132 & Üniversite & $-0,17621 *$ & 0,08216 & 0,082 \\
\hline
\end{tabular}

Söz konusu farklılığı yaratan grup ya da gruplar için belirlenmiş olan çoklu karşılaştırma verileri Tablo 15 'de sunulmuştur. Tablo 15 'deki verilere göre geliri üniversite mezunu olan tüketicilerin sosyal pazarlama faaliyelerine yönelik tutum ve satın alma davranışları diğer eğitim seviyesindeki tüketiciler ile farklılık göstermektedir.

Tablo 16. Meslek ve Tüketici Davranışlarına Illişkin Varyans Analiz Sonucu

\begin{tabular}{llccccc}
\hline & Varyans Kaynakları & KT & Sd. & KO & F & p \\
\hline \multirow{4}{*}{ Tutum } & Gruplararası & 1,232 & 3 & 0,411 & & \\
& Grup içi (hata) & 258,709 & 379 & 0,683 & 0,602 & 0,614 \\
& Toplam & 259,941 & 382 & & & \\
\multirow{3}{*}{ Niyet } & Gruplararası & 0,584 & 3 & 0,195 & & \\
& Grup içi (hata) & 188,067 & 379 & 0,496 & 0,392 & 0,759 \\
& Toplam & 188,651 & 382 & & & \\
\hline \multirow{3}{*}{ Davranış } & Gruplararası içi (hata) & 4,059 & 3 & 1,353 & & \\
& Toplam & 218,979 & 379 & 0,578 & 2,342 & 0,073 \\
& & 223,038 & 382 & & & \\
\hline
\end{tabular}

Tablo 16'da görüldüğü gibi tüketicilerin sosyal pazarlama faaliyetlerine yönelik tutum ( $F:$, 602; $p>0,05)$, niyet $(F: 2,342 ; p>0,05)$ ve davranışlarında ( $F:$,392; $p>0,05)$ gruplar arasında anlamlı bir farklııı saptanamamıştır.

Demografik değişkenlerin tutum, niyet ve gerçekleşen davranış üzerindeki etkilerini ölçmek maksadıyla $\mathrm{H}_{4}, \mathrm{H}_{5}, \mathrm{H}_{6}, \mathrm{H}_{7}$ ve $\mathrm{H}_{8}$ hipotezleri oluşturulmuştur. Yapılan analizler sonucunda cinsiyet, gelir ve eğitim durumunun tüketicilerin sosyal pazarlama faaliyetlerine yönelik tutum ve davranışları üzerinde faklılaştırıcı bir etkisinin olduğu anlaşılmıştır. Tüketicilerin yaşlarının yalnızca tüketicilerin sosyal pazarlama faaliyetlerine karşı tutumları üzerinde farklı etkileri olduğu tespit edilirken, meslek özelliğinin herhangi bir etkisinin olmadığı anlaşılmıştır.

Tüketicilerin sosyal pazarlama faaliyetlerine yönelik tutum, niyet ve satın alma davranışları değerlendirildiğinde, özellikle sağlık, spor, kültür, çevre ve enerji gibi konularda işletmelerin kitle iletişim araçları ile yaptıkları faaliyetlerin ve sponsorlukların tüketicilerin sosyal konulara olan duyarlılıklarını etkilediği anlaşılmaktadır. Ayrıca sosyal fayda yaratan işletmelerin katılımcılar tarafından daha fazla tercih edildiği anlaşılmaktadır. Katılımcılar, sosyal pazarlama faaliyetleri yürüten işletmeleri tekrar tercih edeceklerini belirtmişler ve sosyal pazarlama faaliyetlerinin işletmeler için sadık müşteri yaratmak için bir avantaj olduğunu ortaya çıkarmışlardır. 
Elde edilen bulgular literatürde incelenen bazı çalışmalar ile de desteklenmektedir. Türkoğlu (2016) yaptığı çalışmada tüketicilerin sosyal pazarlama faaliyetlerine önem veren markalara ederlerinden daha fazla ücret ödeyebileceklerini, Sert (2017) yaptığı çalışmada işletmelerin sosyal pazarlama faaliyetlerinin tüketicilerin satın alma davranışları üzerinde olumlu bir etkisinin olduğunu tespit etmiştir. Çetinkaya ve Ceylan (2017) çalışmasında bilinçlenen tüketicilerin sosyal pazarlama faaliyetleri yürüten işletmeleri daha fazla tercih ettiklerini, Korucuk ve Çetin (2019) ise tüketicilerin farkındalıklarının artırıması ile doğru orantılı olarak sosyal pazarlama faaliyetlerine yönelik satın alma niyetinin ve davranışının artacağını belirtmişlerdir.

Tüketicilerin demografik özellikleri ile sosyal pazarlama faaliyetlerine karşı davranışları arasındaki ilişkilerin araştırıldığı hipotezler incelendiğinde; cinsiyet (Armağan ve Karatürk, 2014; Sert, 2017), gelir (Armağan ve Karatürk, 2014; Şahin, Meral ve Aytop, 2016) ve eğitim durumunun (Sert, 2017; Şahin vd., 2016) tüketicilerin sosyal pazarlama faaliyetlerine yönelik tutum ve davranışları üzerinde farkılış̧ırıcı bir etkisinin olduğu ve daha önceden yapılmış olan çalışmalar ile bu bulguların desteklendiği anlaşılmıştır. Tüketicilerin yaşlarının yalnızca tüketicilerin sosyal pazarlama faaliyetlerine karşı tutumları üzerinde farklı etkileri olduğu tespit edilirken (Dinar, 2018), meslek özelliğinin herhangi bir etkisinin olmadığı (Gemlik vd., 2019) anlaşılmıştır. Demografik özellikler ve sosyal pazarlama faaliyetlerine yönelik literatür incelendiğinde bazı çalışmalar ile elde edilen bulguların desteklendiği anlaşılmıştır.

\section{Sonuç}

Küreselleşme ve dolayısıyla bunun etkisi ile yaygınlaşan sosyal farkındalık, işletmeleri, kâr amacı olmadan, yalnızca sosyal fayda için faaliyetlerde bulunmaya yönlendirmiştir. Ayrıca işletmeler yalnızca sosyal pazarlama faaliyetleri ile kalmayıp aynı zamanda gerek toplumsal gerekse çevre barışı adına da adım atmak zorunluluğu hissetmektedirler.

Sosyal pazarlama ve tüketici davranışları ile ilgili yapılan çalışmalar incelendiğinde genellikle, çevreci pazarlama (Çabuk ve Nakıboğlu, 2003), yeşil ürüne karşı tutumlar (Karaca Yılmaz, 2013), sosyal pazarlama kavramının analizi (Kurtoğlu, 2007) ve kurumsal sosyal sorumluluk (Aktan ve Börü, 2007) gibi konular üzerinde çalışmalar yapıldığı tespit edilmiştir.

Gerçekleştirilen çalışma sonucunda, tüketicilerin genellikle spor, sağlık (Kotler ve Lee, 2008), kültür (Pérez ve Bosque, 2013; Okan, Peker ve Demirelli, 2015), çevre (Demirgüneş, 2015; Çakır ve Arslan, 2016) ve enerji gibi konularda sosyal fayda yaratan ve bunu da kitle iletişim araçları ile topluma yayan işletmeleri tercih ettikleri anlaşılmışır. Ayrıca katılımcıların, sosyal fayda yaratan işletmelerin ürünlerine aynı kalitede başka bir ürüne kıyasla daha fazla para harcadığı (i̇zmir ve Turgut, 2019) anlaşıımıştır. İşletmelerin sosyal pazarlama faaliyetlerini sivil toplum kuruluşları ile birlikte yürütmeleri kampanyalarının etkinliğini artırmak için bir yöntem olabilir. Bunlara ilave olarak, katılımcılar sosyal pazarlama faaliyetlerinde bulunan işletmeleri tekrar tekrar tercih edeceklerini belirterek, sosyal pazarlamanın sadık müşteri yaratmada da etkin bir rolü olduğunu göstermektedir (Onurlubaş ve Dinçer, 2016; Koçoğlu ve Koçoğlu, 2017; Yavuz ve Ünal, 2018). Çalışma sonucunda tespit edilen bulgular, literatür araştırması sonucu belirtilen çalışmalarla da desteklenmektedir.

Çalışmaya katılan tüketicilerin demografik özelliklerine bakıldığında, kadın tüketicilerin erkeklere kıyasla sosyal pazarlama konusunda daha etkin oldukları; gelir ve eğitim seviyesi yükseldikçe sosyal pazarlama faaliyetlerine destek ve katılımın arttığı; 35 yaş ve altındaki yaşlara sahip tüketicilerin sosyal pazarlama faaliyetlerine daha fazla önem verdiği ve bu faaliyetleri icra eden işletmeleri destekledikleri görülmektedir. Analizler sonucunda elde edilen bulguların, literatür taramasında bazı çalışmalar tarafından da desteklendiği anlaşılmıştır.

Tüketici davranışlarının özellikle sosyal pazarlama kavramı çevresinde şekillenmesinde işletmeler tüketiciye mesajı iletebilecek tüm yöntemlerle etkin bir kampanya düzenlemelidir. Sosyal konularla ilgili kampanyalar orta ve küçük ölçekli işletmeler için hem zaman hem de maddi anlamda bir yük oluşturabileceğinden, bu tür işletmelerin ortak bir organizasyon altında hem tüketicilere hem de toplumun kalan kesimine hitap etme olasaılığı daha yüksek olacaktır. Ortak organizasyonlar mali kaynak sıkıntısını ortadan kaldıracağı gibi aynı zamanda farklı ve etkin fikirlerin de ortaya çıkmasını sağlayacaktır. 
İşletmelerin sosyal pazarlama faaliyetlerini tasarlarken hedef kitleleri iyi seçmeleri ve çevre aktörlerini de kullanmaları gerekmektedir. Sosyal pazarlama stratejileri vasıtasıyla tüketicilerin tutum, niyet ve satın alma davranışlarında bir farklılık yaratmak için sosyal hedeflerle pazarlama hedeflerinin örtüşmesi gerekmektedir. Ayrıca kitle iletişim araçlarının yanı sıra sosyal medya gibi iletişim araçları ile bu faaliyetlerini tüketicilere duyurmalılardır.

Tüketicilerin sosyal, toplumsal ve çevreci konularda sorumluluklarını yerine getirmelerine yardımcı olan sosyal pazarlama faaliyetleri, işletmelerin samimi ve doğru stratejileri ile kalıcı bir davranış haline gelebilmektedir. İşletme ve stratejileri ile ilgili şüphe duyan tüketiciler, tutum ve niyetlerini satın alma davranışına dönüştürmekten çekinmektedirler. İşletmeler yasal ve etik kurallar çerçevesinde tüketicilere en doğru ve yalın şekilde faaliyetleri hakkında farkındalık yaratmalılardır.

Bu çalışmanın, konu ile ilgili olan işletmeler için rekabet üstünlüğünü yakalamak anlamında kullanabilecekleri bir referans çalışma olabileceği ve akademik çalışmalar için de yardımcı kaynak niteliği taşıyabileceği değerlendirilmektedir. Gelecekte yapılacak çalışmalar için Türkiye'de bulunan tüketicilere değil, farklı ülke ve milletler için de uygulanabilir. Sosyal pazarlama faaliyetleri hakkında yabancı işletme ve tüketicilerin de incelenmesi hem farklı ülkelerin tüketicilerinin hem de toplumların karşılaştııılması için imkânı verebilir.

\section{Beyan ve Açıklamalar (Declarations and Disclosures)}

Yazarların Etik Sorumlulukları (Ethical Responsibilities of Authors): Bu çalışmanın yazarı, araştırma ve yayın etiği ilkelerine uyduğunu kabul etmektedir.

Çıkar Çatışması (Conflicts of Interest): Yazar tarafından herhangi bir çıkar çatışması beyan edilmemiştir.

Finansal Destek (Funding): Yazar, çalışmanın hazırlanması ve/veya yayınlanması sürecinde herhangi bir finansal destek almamıştır.

Yazar Katkı Oranı (Author Contributions): Yazar; kavramlaştırma ve çalışma dizaynı, verilerin toplanması, verilerin analizi ve sonuçların yorumlanması, çalışmanın ilk/taslak halinin yazılması, çalışmanın gözden geçirilmesi ve düzenlenmesi/düzeltilmesi aşamalarından tek başına sorumlu olduğunu beyan etmektedir.

Intihal Denetimi (Plagiarism Checking): Bu çalışma, intihal tarama programı kullanılarak intihal taramasından geçirilmiştir.

\section{Kaynaklar}

Ajzen, I. (1985). The theory of planned behavior. Organizational Behavior and Human Decision Processes, (50), 11-39.

Akdoğan, M. Ş., Çoban, S., \& Öztürk, R. (2012). Medyada yer alan sosyal pazarlama kampanyalarına yönelik tüketici değerlendirmeleri: Konya ilinde bir uygulama. Erciyes Üniversitesi iktisadi ve Idari Bilimler Dergisi, (39), 1-18.

Aktan, C. C., \& Börü, D. (2007). Kurumsal sosyal sorumluluk. (Ed.) C. C. Aktan, Kurumsal sostal sorumluluk: Işletmeler ve sosyal sorumluluk (ss.7-25). Iktisadi Girişim ve Iş Ahlakı Derneği Yayını.

Andreasen, A. R. (1995). Marketing social change: Changing behavior to promote health, social development and the environment. San Francisco: Jossey-Bass Publishers.

Armağan, E., \& Karatürk, H. E. (2014). Yeşil pazarlama faaliyetleri çerçevesinde Aydın bölgesindeki tüketicilerin çevreye duyarlı ürünleri kullanma eğilimlerini belirlemeye yönelik bir araştırma. Organizasyon ve Yönetim Bilimleri Dergisi, 6(1), 1-17.

Aşıkoğlu, D. (2019). Yeşil pazarlamanın kadın tüketicilerin satın alma davranışına etkisi. İstanbul Ticaret Üniversitesi Sosyal Bilimler Enstitüsü, Yayımlanmamı̧̧ Yüksek Lisans Tezi, İstanbul.

Bayraktaroğlu, G., \& ilter, B. (2007). Sosyal pazarlama: Engeller ve öneriler. Ege Akademik Bakış, 7(1), 117-132.

Bozkurt, A. K., \& Avcıkurt, C. (2019). Planlanmış davranış teorisi ile yerli y kuşağı turistlerin destinasyon tercih etme niyetlerinin belirlenmesi. Afyon Kocatepe Üniversitesi Sosyal Bilimler Dergisi, 21(4), 1294-1307.

Büyüköztürk, Ş. (2002). Faktör analizi: Temel kavramlar ve ölçek geliştirmede kullanımı. Kuram ve Uygulamada Eğitim Yönetimi, 32, 470-483. 
Carrington, M. J., Neville, B. A., \& Whitwell, G. J. (2010). Why ethical consumers don't walk their talk: Towards a framework for understanding the gap between the ethical purchase intentions and actual buying behavior of ethically minded consumers. Journal of Business Ethics, 97(1), 139-158.

Cheng, H., Kotler, P., \& Lee, N. (2011). Social marketing for public health: Global trends and success stories. Massachusetts: Jones and Bartlett Publishers.

Crespo, A. H., \& Bosque, I. R. (2008). The effect of innovativeness on the adoption of B2C E-commerce: A model based on the theory of planned behavior. Computers in Human Behavior, 24(6), 2830-2847.

Çabuk, S., \& Nakıboğlu, M. A. B. (2003). Çevreci pazarlama ve tüketicilerin çevreci tutumlarının satın alma davranışlarına etkileri ile ilgili bir uygulama. Çukurova Üniversitesi Sosyal Bilimler Enstitüsü Dergisi, 12(12), 39-54.

Çakır, M. (2012). Development and validation of B2C e-commerce adoption model: An empirical investigation using structural equation modeling and interpretative phenomenological analysis. The Graduate School of Informatics of The Middle East Technical University, Unpublished PhD Thesis, Ankara.

Çakır, A., \& Arslan, B. (2016). Kurumların uyguladıkları sosyal sorumluluk projelerinin tüketicilerin marka sadakati üzerine etkileri: Otomobil markaları üzerine bir araştırma. Manisa Celal Bayar Üniversitesi Sosyal Bilimler Dergisi, 14(2), 437-452.

Çetinkaya, C., \& Özceylan, E. (2017). Üniversite öğrencilerinin yeşil satın alma tutumlarının incelenmesine yönelik bir araştırma: Gaziantep üniversitesi örneği. Gaziantep University Journal of Social Sciences, 16(1), 289-302.

Çokluk, Ö., Şekercioğlu, G., \& Büyüköztürk, Ş. (2014). Sosyal bilimler için çok değişkenli istatistik ve SPSS ve LISREL uygulamaları. Ankara: Pegem Akademi.

David, P., \& Rundle-Thiele, S. (2018). Social marketing theory measurement precision: A theory of planned behaviour illustration. Journal of Social Marketing, 8(2), 182-201.

Davis, F. D. (1989). Perceived usefulness, perceived ease of use and user acceptance of information technology. MIS Quarterly, 13(3), 319-340.

Demirağ, F. (2020). Planlı davranış teorisi çerçevesinde elektronik ağızdan ağıza iletişimin satın almaya etkisi. izmir iktisat Dergisi, 35(2), 241-253.

Demirgüneş, B. K. (2015). Sosyal sorumluluk projelerine yönelik tutumun, satın alma davranışı ve satın alma niyeti üzerindeki etkisi. Hacettepe Üniversitesi Iktisadi ve Idari Bilimler Fakültesi Dergisi, 33(3), 47-74.

Dinar, N. (2018). Yeşil reklamların ve çevre bilincinin yeşil ürün satın alma niyeti üzerine etkisi. Marmara Üniversitesi Sosyal Bilimler Enstitüsü, Yayınlanmamış Yüksek Lisans Tezi, İstanbul.

Erten, S. (2002). Planlanmış davranış teorisi ile uygulamalı ders işleme öğretim metodu. Hacettepe Üniversitesi Edebiyat Fakültesi, 19(2), 217-233.

Ewing, M. T. (2001). Social Marketing. The Haworth Press. USA.

Farrukh, M., Yazan, A., Imran, A., Shahzad, A., \& Waheed, N. K. (2018). Entrepreneurial intentions: The role of personality traits in perspective of theory of planned behaviour. Asia Pacific Journal of Innovation and Entrepreneurship, 12(3), 399-414.

Gemlik, N., Arslanoğlu, A., Gün, M., \& Aslan, Ü. (2019). Hastane yöneticilerinin yeşil hastane farkındalığı üzerine nitel bir araştırma, Uluslararası Sosyal ve Beşeri Bilimler Araştırma Dergisi, 6(40), 2135-2144.

Hair, J. R, Black, W. C., \& Babin, B. J. (2010). Multivariate data analysis: A global perspective. New Jersey: Upper Saddle River Pearson Education, Inc.

Hatcher, L. (1994). A step by step approach to using the SAS system for factor analysis and structural equation modeling. Cary, N.C.: SAS Institute.

Iftekhar, H., Ayub, A., Razzaq, A., \& Aslam, M. S. (2013). Detrimental effects of marketing practices on consumers' buying behaviors. Business Management Dynamics, 2(10), 1-5.

İzmir, O., \& Turgut, A. B. (2019). Kurumsal sosyal sorumluluk algısının satın alma niyeti ve yüksek fiyat verme isteği üzerindeki göreli etkilerinin tespiti. Küresel Iktisat ve Iş̧letme Çalışmaları Dergisi, 8(5), 133-151.

Kağıtçıbaşı, Ç., \& Cemalcılar, Z. (2015). Dünden bugüne insan ve insanlar, sosyal psikolojiye giriş. İstanbul: Evrim Yayınevi.

Karaca Yılmaz, Ş. (2013). Tüketicilerin yeşil ürünlere yönelik tutumlarının incelenmesine yönelik bir araştırma. Ege Akademik Bakış Dergisi, 13(1), 99-111.

Kim, D., \& Benbasat, I. (2003). Trust-related arguments in internet stores: A framework for evaluation. Journal of Electronic Commerce Research, 4(2), 49-64.

Kline, R. B. (2011). Principles and practice of structural equation modeling. New York: The Guilford Press. 
Koçoğlu, C. M., \& Koçoğlu, Y. (2017). Yeşil pazarlama kapsamında çevreye duyarlı ürünlerin satın alma eğilimleri: Lisans düzeyinde turizm eğitimi alan öğrenciler üzerinde bir araştırma. Uluslararası Yönetim Iktisat ve Işletme Dergisi, Özel Sayı, 417-427.

Korucuk, N., \& Çetin, A. F. (2019). Yeşil pazarlama bağlamında yeşil ürünlere ilişkin tüketici satın alma davranışı: Kafkas Üniversitesi örneği. Kafkas Üniversitesi Iiktisadi ve Idari Bilimler Fakültesi Dergisi, 10(19), 250-289.

Kotler, P., \& Armstrong, G. (2018). Pazarlama ilkeleri. İstanbul: Beta Yayıncılık.

Kotler, P., \& Nancy, R. L. (2008). Social marketing: Influencing behaviors for good (Third Edition). California: Sage Publications.

Kotler, P., \& Roberto, E. L. (1989). Social marketing: Strategies for changing public behavior. Detroit: Free Press.

Kotler, P., \& Zaltman, G. (1971). Social marketing: An approach to planned social change. Journal of Marketing, 35(3), 3-12.

Kurtoğlu, S. (2007). Sosyal pazarlama kavramının analizi. Sosyal Bilimler Dergisi, (1), 125-134.

Linan, F., \& Chen, Y. W. (2009). Development and cross-cultural application of a specific instrument to measure entrepreneurial intentions. Entrepreneurship Theory and Practice (ETP), 33(3), 593-617.

Ma, W. W., Anderson, R., \& Streith, K. O. (2005). Examining user acceptance of computer technology: An empirical study of student teachers. Journal of Computer Assisted Learning, 21(6), 387-395.

Manzano, N., Rivas, L., \& Bonilla, G. (2012). Explanatory models of change of consumer behavior applied to social marketing. Scientific Research, 4, 246-255.

Mert, G. (2012). Sosyal pazarlama uygulamalarının tüketici davranışı ve firma performansı üzerine etkileri: Teori ve bir uygulama. Organizasyon ve Yönetim Bilimleri Dergisi, 4(1), 117-129.

Meydan, C. H., \& Şeşen, H. (2011). Yapısal eşitlik modellemesi AMOS uygulamaları. Ankara: Detay Yayıncılık.

Moore, G. C., \& Benbasat, I. (1991). Development of an instrument to measure the perceptions of adopting an information technology innovation. Information Systems Research, 2(3), 173-239.

Oğuz, G. V., \& Bilgen, ì. (2017). Kurumsal sosyal sorumluluğun satın alma niyeti üzerindeki etkisi: İstanbul ilinde bir araştırma. iGÜ Sosyal Bilimler Dergisi, 4(2), 51-72.

Okan, T., Peker, I., \& Demirelli, S. (2015). A corporate social responsibility framework for mining sector using analytic network process. International Business Research, 8(12), 9-25.

Onurlubaş, E., \& Dinçer D. (2016). Yeşil pazarlama tüketici algısı üzerine bir araştırma. İstanbul: BETA Yayınevi.

Perez, A., \& Del Bosque, I. R. (2013). Measuring CSR image: Three studies to develop and to validate a reliable measurement tool. Journal of Business Ethics, 118(2), 265-286.

Raghunathan, R., \& Trope, Y. (2002). Walking the tightrope between feeling good and being accurate: Mood as a resource in processing persuasive messages. Journal of Personality \& Social Psychology, 83(3), 510-525.

Sert, A. (2017). Yeşil pazarlama ve tüketicilerin satın alma davranışları: Üniversite öğrencilerine yönelik bir araştırma. Nişantaşı Üniversitesi Sosyal Bilimler Enstitüsü, Yayınlanmamış Yüksek Lisans Tezi, İstanbul.

Şahin, A., Meral, H., \& Aytop, Y. (2016). Yeşil pazarlamada tüketici algısı: Kahramanmaraş kent merkezi örneği. Anadolu Tarım Bilimleri Dergisi, (31), 60-71.

Tabachnick, B. G., \& Fidell, L. S. (2013). Using multivariate statistics. Boston: Person Education Inc.

Tek, Ö. B. (1999). Pazarlama ilkeleri. İstanbul: BETA Yayınları.

Türkoğlu, A. (2016). Examinating the effects of green marketing on the purchasing behaviours of consumers in sociodemographic aspects. Bahçeşehir University, The Institute of Social Sciences, Unpublished Master Thesis, İstanbul.

Yapraklı, Ş., Noksan, E., \& Ünalan, M. (2017). Tüketicilerin sosyal sorumluluk projelerine yönelik genel tutumlarının marka sadakati ve satın alma niyeti üzerindeki etkisi. МСBÜ Sosyal Bilimler Dergisi, 15(4), 133-154.

Yanık, A. (2014). Yeni medya kullanımındaki akış deneyiminin risk algısı ve online turistik satın alma niyetine etkisi. Adnan Menderes Üniversitesi Sosyal Bilimler Enstitüsü, Yayımlanmamış Doktora Tezi, Aydın.

Yavuz, E., \& Ünal, S. (2018). Bilişsel ve marka güveninin satın alma davranışı üzerindeki etkisi: Erzurum ilinde bir araştırma. Atatürk Üniversitesi Iktisadi ve Idari Bilimler Dergisi, 32(2), 247-266.

Yıldırır, S. C. (2016). The impact of social marketing applications on customer's behavior and customer loyalty. International Journal of Economics, Commerce and Management, 4(5), 283-296. 
Yılmaz, C., \& Tümtürk, A. (2015). İnternet üzerinden alışveriş niyetini etkileyen faktörlerin genişletilmiş teknoloji kabul modeli kullanarak incelenmesi ve bir model önerisi. Yönetim ve Ekonomi: Celal Bayar Üniversitesi iktisadi ve Idari Bilimler Fakültesi Dergisi, 22(2), 355-384.

Yılmaz Yaman, S. (2018). Kadınların internetten satın alma davranış sürecini etkileyen faktörler. İstanbul Ticaret Üniversitesi Sosyal Bilimler Enstitüsü, Yayımlanmamış Yüksek Lisans Tezi, İstanbul. 
This Page Intentionally Left Blank 